\title{
LESSOR'S STATUS IN LAND CONSOLIDATION IN EUROPE - REPORTS FROM CYPRUS, FINLAND, FRANCE, GERMANY, THE NETHERLANDS, LATVIA AND ESTONIA
}

\author{
Kimmo SULONEN ${ }^{1}$, Seija KOTILAINEN ${ }^{2}$ \\ 1,2 Aalto University, Finland \\ Kimmo.sulonen@gmail.com \\ siekotil@gmail.com
}

\begin{abstract}
The purpose of this research was to investigate a landowner's status as a lessor in land consolidation on agricultural areas in Europe. The research was based on surveys designed for land consolidation experts from Cyprus, Finland, France, Germany, the Netherlands, Latvia, Estonia and statistical data of the areas. The lease of agricultural land is common in Europe. However, there are differences related to how common the lease is and what the rental value of land is. The variation is based on factors such as differences in the markets, historical development of the agricultural lands and current legislation. The lessors have rights as landowners in land consolidation, but in case the land is used by third parties, lessor's status is more limited compared to other landowners'. Similarly the costs of land consolidation typically are paid by landowners, not by users. The lessors are commonly indifferent and suspicious about the land consolidation. They are occasionally suspicious, especially before or at the beginning of the process, but later on they seem to be less suspicious. The lessors' experience of land consolidation is based commonly on a fear of additional costs for their investment.
\end{abstract}

Keywords: Land consolidation, landowner, leaseholder, lessor, survey study.

\section{INTRODUCTION}

Agricultural use of land has long traditions in Europe and it still has a role in the European economy. The significance of agriculture is seen, for example, in politics where the Common Agricultural Policy (CAP) has been present nearly since the foundation of the European Union (EU 2012).

The land use in rural areas is normally less controlled than in urban areas. Land transactions, such as purchase or lease, by farmers who increase their capacity, can cause land division to fragment and to lose the benefits of the newly acquired land ${ }^{1}$ (Vitikainen, 2004, pp. 39-40). Additionally, insecurity of continuation of the lease can lead to long-term decline of land improvements in those leased fields (Myyrä, 2009, pp. 17, 20-22).

To investigate the lessor's situation, the primary research question was introduced: "What is the lessor's status in land consolidation in different areas in Europe?" Moreover, to clarify the lessor's status, it was essential to examine:

${ }^{1}$ This is due to issue that sold or leased parcel might end up to other users than those who have adjacent parcels or those that profit most of the parcels (Vitikainen, 2003, p. 8). 
What is the situation of the agricultural land lease in surveyed areas? What is the lessor's status in land consolidation in comparison with other groups? How do lessors seem to experience the land consolidation?

In this research, the purpose was not inclusively to study all the differences in land consolidation, lease or agricultural situation altogether, but rather to concentrate on investigating factors that can explicate the lessor's status in different countries. The focus of this article is mainly on land consolidation and lease on cultivated agricultural lands not, for example, on forestry areas or urban areas.

\section{GENERAL METHODS AND MATERIALS}

To investigate the answers to the aforementioned research problem, a special survey was conducted to selected specialists from different areas of Europe. The areas and specialists were selected based on several criteria. First of all, one of them was to select areas from different parts of Europe. The size of the areas was set to cover a country or a state. The second criterion was to find out areas where the land consolidation processes were common ${ }^{2}$ and relatively similar, preferably from the lessor's point of view. The criteria for selecting a specialist were that the person had expertise in the topic nationwide ${ }^{3}$ and was responsible for land consolidation in that area. To find out these specialists and their contacts, prior investigations were required. The investigation included separate queries to these contacts until suitable specialists were found ${ }^{4}$. The survey was sent to 29 different recipients ${ }^{5}$. Whether the land consolidation was conducted by cadastral surveyors as administrative authorities ${ }^{6}$ or by a committee ${ }^{7}$ was not considered a significant difference from the lessor's point of view.

While the purpose of the survey was to collect information from various international contacts, the email-based approach was seen the most suitable method for conducting the survey. The survey was planned to be simple and open, where defined questions were given as guidelines, thus allowing participants (of the survey) to answer without strictly following the structure of the form. The questions were based on the following pre-defined factors: commonness of land lease, price (rent), lease contracts (length), status of the lease (lessor), costs of land lease and lessor's attitude. This kind of method produces qualitative data, in

\footnotetext{
${ }^{2}$ In the UK, for instance, there is not a similar kind of activity with land consolidation as in the aforementioned countries (Demetriou et al., 2013, p.8).

${ }^{3}$ From a country or area that a specialist was representing.

${ }^{4}$ The contact addresses for the survey were obtained from different sources such as published articles and by interviewing second-degree contacts. Therefore, most difficulties during the survey occurred while finding out and identifying survey participants and their contact email addresses.

${ }^{5}$ Five of the recipients were general addresses and 24 of them were personal addresses. Seven of them did not respond and three of the contact addresses were obsolete and unable to deliver. The overall respond rate was $65 \%$. This does not include obsolete addresses.

${ }^{6}$ This method is present in many countries, such as in Germany and Finland (Vitikainen 2004).

${ }^{7}$ This method is present in Western Europe, for example, in the Netherlands and France.
} 
which way the responses were examined. The time of the survey was between autumn 2014 and spring $2015^{8}$.

As a result, ten responses were selected to represent the surveyed areas from Cyprus, Germany, Bavaria (Germany), France, Estonia, the Netherlands and Latvia. In Latvia and Estonia, the land consolidation legislation and procedures have recently or will be changing, weighting the results more to the theoretical basis compared to the empirical basis of land consolidation. Additionally, the data from previous survey ${ }^{9}$ (Sulonen, 2014) collected in 2013 autumn was used for information about Finland.

The additional statistical data were acquired, such as prices of the land and area of leased field parcels and total leased areas as background information. The material was not used for quantitative analyses of the topic, but rather to help understand the differences and significance of the land lease in different areas.

\subsection{LAND LEASE}

One of the interest groups in land consolidation on agricultural areas is lessors. Lessors are landowners who give the right to use their own land to those who need it without giving away their ownership of the land for compensation ${ }^{10}$. If the lessor leases his/her lands for investment purposes the lessor normally aims to maximise income out of the property with minimal investments and, therefore, may not actively consider how to improve the land by different means such as by land consolidation. However, there are lessors who lease their lands for other reasons, such as in order to preserve them for the next generation and merely covering the costs of the lands by leasing them. The aforementioned method is common, for example, in Finland (Sulonen, 2014, pp. 32-33; Sulonen \& Kotilainen, 2016, pp. 4-6).

\subsection{THE STATUS OF LEASE}

The importance of lease markets in many countries of the European Union is based on factors such as transaction costs, other related markets and historical inheritance development. Historically, in some areas it was the eldest son who had the inheritance rights and in some areas the land was split among all children (Ciaian et al., 2012, pp. 4-5). The legislative differences have an effect on the lease markets as well. For example, in France, Belgium and the Netherlands, officials regulate the rents (Ciaian et al., 2012, pp. 6-7). The proportion of leased land of the total agricultural land area is seen in Fig. 1.

\footnotetext{
${ }^{8}$ The survey was sent to participants when the contact information was available. More detailed information about the survey-conversations is presented in the references.

9 The survey was for a wide range of lessors and key land consolidation specialists, currently working on conducting the procedures in Finland. (Sulonen, 2014).

${ }^{10}$ If the action does not involve compensation to the party giving away land use right, the action is considered a loan rather than a lease. (Saarnilehto, 2006, pp. 2-4).
} 


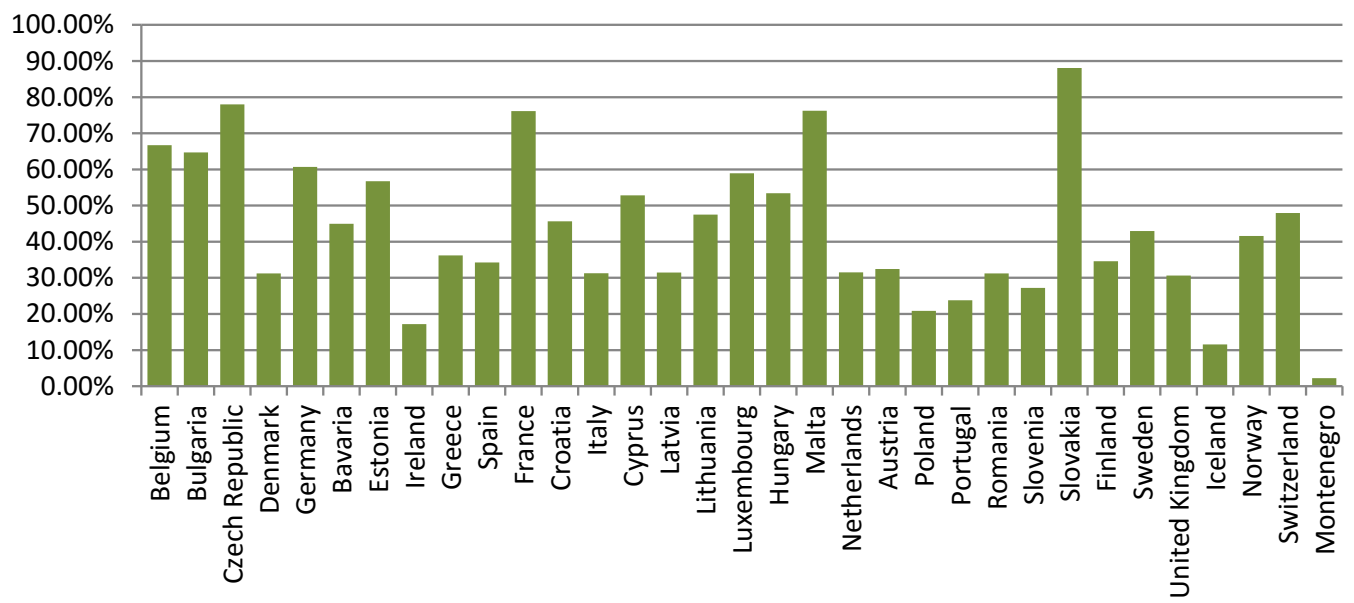

Fig. 1. Percentage of leased agricultural land of total agricultural land area in 2010. (Eurostat 2015). Based on number of farms and areas by agricultural size of farm (UAA). ${ }^{11}$

The average rent varies in different areas of Europe along with the average price of these fields. The rent and field prices seem to have more value in CentralEuropean countries and especially in the Netherlands, Denmark and areas close to these countries, for example in Germany (north-west) and in France (north). In contrast, the value of rent and field prices are lower in other areas, such as in Cyprus and in Eastern and Northern Europe. To visualise the differences, the average rent per hectare is presented in Fig. 2.

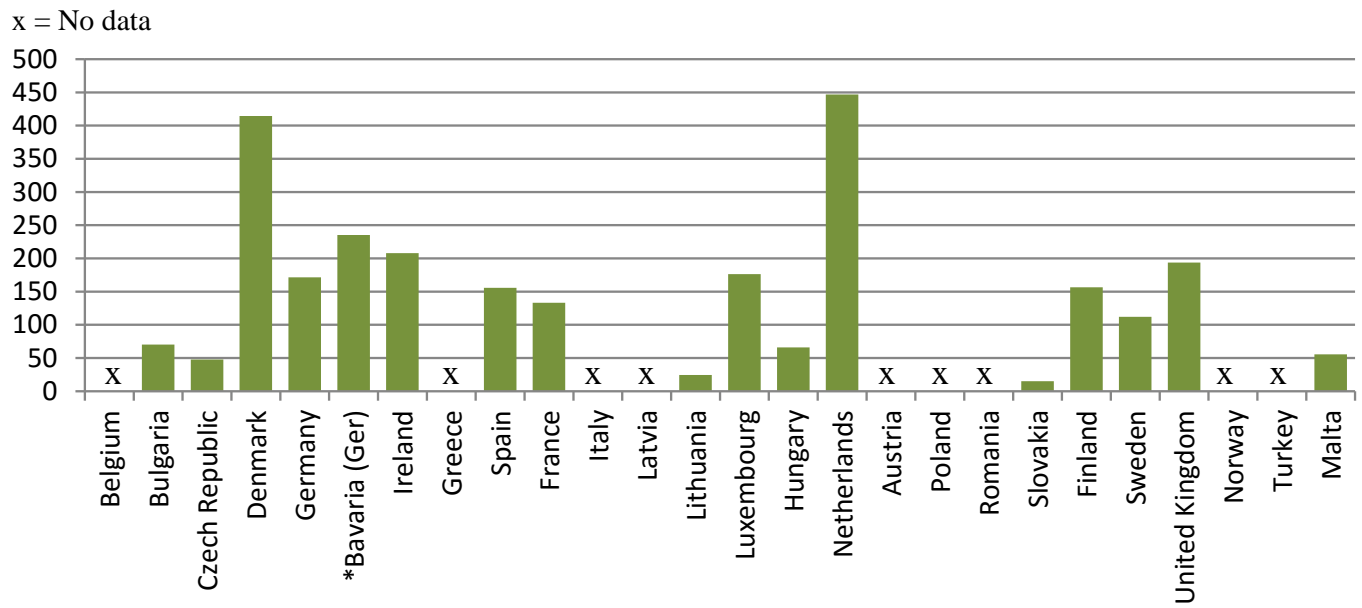

Fig. 2. Average rent of agricultural land in EUR per hectare (2000-2009) of displayed countries and Bavaria 2001-2010. (Eurostat, 2015; Agrarbericht, 2012).

${ }^{11}$ Utilised agricultural area (UUA) is the total area taken up by arable land, permanent pasture and meadows, land used for permanent crops and kitchen gardens (EU, 1987). 


\section{LEASE IN LAND CONSOLIDATION AREAS IN EUROPE}

\subsection{LEASED AREA}

\section{Germany}

On average, more than $60 \%$ of agricultural lands are leased in Germany. The situation is different in former western- and eastern-parts of the country, as the lease is significantly more common in the former Eastern part ${ }^{12}$. The tendency is that the gap between how common the lease is in the former Eastern and Western parts is decreasing (DBV, 2014, pp. 56-59; Thomas, 2015). The state of Bavaria is in different class at this matter, being the only state in Germany where cultivating on the leased land is less common compared to cultivating on the owned land $^{13}$ (Agrarbericht, 2012; Gollwitzer, 2013).

\section{The Netherlands}

In the Netherlands, the average lease percentage of agricultural lands is 30-40 \%. The lease percentage varies greatly between regions, mostly for historical reasons. (CBS, 2007; Eurostat, 2015; Louwsma, 2014.) The proportions may change in the future because of the current protective rules, which are in favour of leaseholders and cause owners often not to start a new lease (Zevenbergen, 2014).

\section{France}

The lease is especially common in France, but varies through the country from $50 \%$ to $88 \%$ and being around $70 \%$ on average. The lease is more common in the north of the country compared to the south of the country, especially in areas close to the border of Belgium (Eurostat, 2015).

\section{Finland}

The average proportion of the leased land area in Finland is ranging between $30-40 \%$ of total cultivated lands. The proportion of the land lease varies in different areas of the country because of different types of landscapes. Furthermore, it is notable that the proportion of agricultural landowners acting as lessors is greater compared to the proportion of the leased agricultural area of total land area. The main reason for this is that lessors own less land compared to active landowners. The lease is common, but the reasons to lease are various; such as to hold the land for the next generation ${ }^{14}$, lease it to a relative, have the fields leased when there is no other use of land and purely for investment purposes. The first reasons are more common compared to leasing land for investment (Sulonen \& Kotilainen, 2016; Sulonen, 2014, pp. 13-14, 32-37).

\footnotetext{
${ }^{12}$ In the former Western part of Germany, $55 \%$ of the agricultural land was leased and in the former Eastern part of the Germany $71 \%$ was leased in 2014 (DBV, 2014, pp. 56-57).

${ }^{13}$ Leased agricultural land in Bavaria (44.7 \%) (Agrarbericht, 2012; Gollwitzer, 2013).

${ }^{14}$ Thus, lease is temporary part of the process where the land is eventually transferred to the next generation from parent to child (Sulonen, 2014, pp. 32-33).
} 


\section{Cyprus}

The lease on agricultural lands is common, especially in areas where livestock is included in farming activities, as land is leased to produce feed to livestock. However, there is variation between areas (Demetriou, 2014). The average proportion of leased land of total agricultural lands is $50 \%$ (Eurostat, 2015).

\subsection{LEASE PRICE}

\section{Germany}

As the lease is more common in the former Eastern part of Germany compared to the Western part of the country, the average rents of arable farmlands per hectare are smaller in the former eastern part compared to former western part of Germany. The difference ${ }^{15}$ is hundreds of EUR per hectare. The rents in the north-west were up to $600 €$ per hectare in 2014, whereas the German average was $300-400 €$. The tendency is that rents are rising in every area of the country (DBV, 2014, pp. 58-59). In Bavaria, the field prices are substantially greater and rents are above average when compared to other parts of Germany (Agrarbericht, 2012; Eurostat, 2015).

\section{The Netherlands}

Rents in the Netherlands are high in European standards; mainly ranging between 500 and $900 €$ per hectare ${ }^{16}$. The maximum rent is regulated by authorities annually (Louwsma, 2014; Silvis et al. 2014, p. 14).

\section{France}

In France, there are regulations of agricultural lease, such as for pricing the rent. These regulations for the price of the rent are specified in Rural and Maritime Fishing Code (RMFC Article, L. 411-11). The rent is controlled by the authorities and is calculated annually to determine the price range ${ }^{17}$ where a lessor and leaseholder must operate. Therefore, to make a legal lease contract, the participants of the lease must accept the rent that is in the limits of minimum and maximum rent. In addition, the participants must specify the rent in a manner that there must be separate values for the different types of leased buildings and land (Epinat, 2014).

\section{Finland}

The rent per leased field hectare is relatively low by European standards being $100-200 €$ per hectare on average. In many cases, the lease does not provide good income for investors and perhaps that is the main reason why leasing agricultural land as an investment is not common in Finland (Sulonen \& Kotilainen, 2016).

\footnotetext{
${ }^{15}$ In the former Eastern part of Germany average rent of arable farmland was $206 €$ per hectare, in former Western part of Germany average rents were $442 €$ per hectare in 2014 . The average rent in the north-west varied from 551 to $598 €$ per hectare in different states, where in Bavaria the average rent was 466 (DBV, 2014, pp. 58-59).

16 The average rent in the Netherlands was $633 €$ per hectare in 2014 (Silvis et al., 2014).

17 The price range of the rent is based on French national rent reference index (Epinat, 2014).
} 


\section{Cyprus}

The rents of the lease are fairly low being approximately a few hundreds of EUR per hectare per year. The amount of the rent might, nevertheless, vary in different regions (Demetriou, 2014).

\subsection{LEASE PERIOD}

\section{Germany}

On the one hand, in small parcels, the lease contracts are normally made only orally. The contracts continue from year to year, until cancelled. On the other hand, in larger parcels the lease period is commonly between four and nine years (Thomas, 2015). In land consolidation, the contracts are often reorganised. ${ }^{18}$ In Bavaria, during land consolidation, new contracts are made normally for at least ten years (Donaubauer, 2013; Gollwitzer, 2013).

\section{The Netherlands}

The legislation in the Netherlands defines different types of lease contracts, such as the long-term and short-term contracts. The long-term contracts are made for six-year periods and offer stronger rights to leaseholders compared to shortterm lease contracts. At the end of a long-term contract, the leaseholder is capable of renewing the contract for another six years with or without the lessor's consent. In addition, the leaseholder has primary right to buy the land if the lessor wants to sell it. The shorter lease contracts do not grant such rights to the leaseholder, and thus lessors have more commonly been favouring these types of lease contracts. Currently, both contract lengths are common (Louwsma, 2014).

\section{France}

The lease periods in France are at least nine years (RMFC Article, L. 411- 5). This regulation applies to both oral and written contracts, when the lease is renewed. The rule is mandatory, as the new lease period cannot be made shorter than that. However, the lease contracts can be longer, such as for 18 or even 25 years (RMFC Article, L. 416-1).

\section{Finland}

Legally, the land lease is less regulated on plain agricultural areas compared to urban plot areas or land areas with structures ${ }^{19}$. The legislation allows land leases of agricultural lands up to 20 years and up to 25 years if there are buildings suitable for agricultural use (AoT, 258/1966 sections 57 and 71). Despite the legislative possibilities, contracts are made for five years on average (Sulonen, 2014, pp. 42-43).

18 The lease contracts are not cancelled by the land consolidation process and the lease is transferred to the allocated land parcels (Gollwitzer, 2013). This is done unless the participants of the contract wish otherwise.

${ }^{19}$ The land lease in Finland should be applied for the registration if the lease right is transferable to a third party without hearing the titleholder and if the lease contract allows a building in the area or there are buildings in the area that belong to the leaseholder (CRE, 540/1995, chapter 14, sections 1-2). 


\section{Cyprus}

There is no special legislation to either favour or restrict the land lease between private parties. However, if the other party is the state, the lease period is set to one year and continues for each year if not cancelled (Demetriou, 2014).

\subsection{THE STATUS OF LESSOR AND LEASEHOLDER IN LAND CONSOLIDATION}

\section{Germany}

The focus of the land consolidation is mainly based on the ownership of the land. Primarily, lessors as landowners are a participant of the Community of Participants of the land consolidation. Leaseholders are part of the secondary order in land consolidation where they do not have direct influence on plans, such as common and public facilities and reallocation. However, the legal status of the old parcels, such as lease, has to be taken into account in new parcels (Thomas, 2015).

There are alternative methods to improve land use in agriculture instead of land consolidation, where the status of land use is different. Such methods include, for example, the possibility of voluntary exchange of land or land use. In exchange for the land use rights, the exchange is done according to how land is used, whereas land ownership remains unchanged (Gollwitzer, 2013; RDB, 2006, pp. 115-122).

\section{The Netherlands}

All landowners are part of the land consolidation in the consolidated area. The leaseholders in the land consolidation area can apply to register their lease contracts at the beginning of the land consolidation process. The registration requires acceptance of both parties and, hence, is taken into account during the reallocation process (Louwsma, 2014).

From the viewpoint of improving the agricultural situation of the area, the interest of the leaseholder as a land user is more crucial compared to the interest of the lessor in the allocation process. However, the legislation dictates that the lessor's status may not be deteriorated (Louwsma, 2014).

\section{France}

The purpose of the land consolidation is to improve the land use and property values. Where the improvement is not possible in every case, it should not nevertheless decrease the value of the property. Therefore, it is possible that the land consolidation can reach status quo when observing the results from the viewpoint of the single landowner (Epinat, 2014).

In principle, lessors and leaseholders are treated as equals in land consolidation. Moreover, the land consolidation process should be beneficial to everyone. However, when the interest of the lessor and leaseholder are different in reallocation of parcels, lessor's interests prevail. When leased land parcels are reallocated, the lease contract is transferred to new parcels. In these cases the leaseholder either has to accept the change or end the contract (Epinat, 2014). 


\section{Finland}

The legislation states that in land consolidation, the leased area shall be amended to pertain to the lessors' new parcels, unless the change causes considerable hindrance to the leaseholder (REFA, 554/1995, 86§). Practically the lease is transferred along with the lessor's lands if possible without major complications. Additionally, these leased lands are allocated in many cases close to the lands that the leaseholder already uses. This is done if the lessor as a landowner does not object the allocation. The length of the lease generally has an effect on how well the leaseholder's interests are possibly taken into account in land consolidation (Sulonen, 2014, p. 20, 49-50).

\section{Cyprus}

The land consolidation in Cyprus aims at improving the situation in property division originated from an anachronistic system of land tenure, such as land held in undivided form and dual or multiple ownerships (LCDoC, 2015). There are complexities on land ownership where there might be dual or multiple ownership of the land or different resource on it (Demetriou et al., 2013, pp. 3-4).

On land consolidations in Cyprus, the lease is considered a temporary situation where the lessor's, as a landowner, interests are stronger compared to the leaseholder's. In legislation, ${ }^{20}$ it is stated that landowners are invited into hearing with authorities carrying out the land consolidation process. This does not include leaseholders. The legislation requires that the leaseholder's interests have to be noted, if not in conflict with the lessor's interests. Furthermore, the leaseholder's status is noted as fairly as possible, though not in the expense of lessor's status (Demetriou, 2014).

\subsection{COSTS OF LAND CONSOLIDATION}

\section{Germany}

The Land Consolidation Act in Germany states that the cost of the land consolidation is divided among the landowners (LCA section 19). However, the costs can be subsidised by the state (Donaubauer, 2013). In Bavaria, the costs of land consolidation are subsidised up to $80 \%{ }^{21}$ and the remaining expenses are divided among land owners. The landowners, who have long-term lease contracts, may have half of their costs subsidised ${ }^{22}$ (Donaubauer, 2013; Gollwitzer, 2013, LCA 19). The land owner normally passes the costs to the leaseholder by increasing the rent (Thomas, 2015).

20 The implementation of land consolidation in Cyprus follows democratic procedures applied in the European Union Policy. These procedures are based on the Consolidation and Reallocation of Agricultural Land Laws from 1969 to 2003. These laws provide owners to participate in all stages of land consolidation and object them (LCDoC, 2015).

21 The land consolidation is funded by the state of Bavaria, Federal Republic of Germany and EU (Gollwitzer, 2013).

${ }^{22}$ In Bavaria, if landowners have lease contracts for more than ten years, half of their costs can be subsidised (Donaubauer, 2013; Gollwitzer, 2013). 


\section{The Netherlands}

The costs are mainly funded by the state. The leftover costs are divided according to how well the participants benefit ${ }^{23}$ from the land consolidation. The leftover costs are directed to land owners and possibly indirectly to leaseholders, where the lessor can raise the rent in the limits of rent regulations (Louwsma, 2014; Zevenbergen, 2014).

\section{France}

The land consolidation is funded by the department ${ }^{24}$ and the landowners. The department can use funds of the state and the European Union. The work of surveyors, evaluation of impact assessment and implementation of the procedure of land consolidation is funded $100 \%$ by the department. The main responsibility of the other works related to land consolidation is funded by landowners, but is subsidised by $40 \%$ (Epinat, 2014; Derlich, 2002).

\section{Finland}

The majority of the costs of land consolidation is subsidised by the state and the rest of the costs are funded by landowners (UjTL 1423/2014). Distributing of the costs to leaseholders is a challenge, because the lease periods are too short and it is uncertain if the current leaseholder is able to renew the contract. However, the lessors and leaseholders have been distributing the costs after the land consolidation among themselves (Sulonen, 2014, p. 54). In overall, there is a problem to distribute costs to leaseholders when many of the lease contracts in land consolidation areas are made for five years as on average (Sulonen, 2014, pp. 6, 43). This is common, despite the fact that legislation allows leases in agricultural lands up to 25 years (AoT, 258/1966, sections 57 and 71).

\section{Cyprus}

The costs of the land consolidation are mainly funded by the state. Landowners' share of the costs is approximately one third of the costs. The landowners cede portions of their lands to road improvements. Commonly the portion is small, $4-7 \%$ of total owned land (Demetriou, 2014).

\subsection{LESSORS' EXPERIENCES}

\section{Germany}

The lessors are currently able to lease their land for sufficient income in Germany. In overall, the lessors tend to be suspicious about land consolidations and how they can transfer the costs to leaseholders. Therefore, they occasionally try to prevent land consolidation in fear of additional costs or losing lands due to new roads. In comparison, the leaseholders as land users typically recognise the benefits of land consolidation. The leaseholders are commonly those who benefit the most of land consolidation, if they do not own any land on the land

\footnotetext{
${ }^{23}$ These factors taken into consideration are, for example, parcel concentration, decrease of the distance to field parcels, increase of parcel sizes (Louwsma, 2014).

${ }^{24}$ Regional administrative divisions of France.
} 
consolidation areas. Occasionally, leaseholders may feel that they lose their status on lease markets over small and adjacent parcels due to land consolidation (Thomas, 2015; Gollwitzer, 2013).

\section{The Netherlands}

The land consolidation might cause some tension between the participants, where some of the lessors become unsatisfied. It is worth mentioning that the lessors, who lease the land for investment purposes, generally are not interested in where their lands are as long as the land holds its value. However, there is no wider study on lessors' opinions (Louwsma, 2014).

\section{France}

The reactions of the lessors are mainly indifferent and rarely openly negative. The lessors tend to experience that the land consolidation is unnecessary and causes costs to them. However, the attitude tends to be temporary and changes. The lessors may propose to be left out of the land consolidation, but if this hinders the purpose of the land consolidation, such requests are typically rejected (Epinat, 2014).

\section{Finland}

The lessors tend to be suspicious towards the land consolidation and its costs. Their experiences ${ }^{25}$ of the land consolidation process are indifferent or slightly positive. The experiences of different phases of land consolidation tend to follow the trend where they are either slightly positive or slightly negative. The lessors had the most positive experience from the road and ditch improvement phases and most negative experience from dividing the costs. The lessor's suspicion before the land consolidation tends to dissolve slightly after the land consolidation (Sulonen \& Kotilainen, 2016, pp. 7, 8, 12 \& 13; Sulonen, 2014, pp. 58-60).

\section{Cyprus}

The experience from land consolidation is overall positive. Approximately four out of five land owners have a positive experience in overall (Demetriou, 2014).

\subsection{THE SITUATION IN THE BALTIC AREA: ESTONIA AND LATVIA}

Due to historical reasons and large land reforms during past decades ${ }^{26}$, the legislative work is in a different state in Eastern Europe compared to Western Europe. In countries such as Latvia and Estonia, there are or will be legislative changes considering land consolidation process (Sproge, 2015; Jürgenson, 2015). This is due to recognition that there is a need for second phase of land reform involving land consolidation to decrease the fragmentation of land parcels, such as in Latvia (Micurova, 2005, p. 2).

\footnotetext{
25 There are minor groups of lessors with strong negative or positive experiences (Sulonen, 2014, pp. 58-60).

${ }^{26}$ For example, there were large land privatization reforms in Latvia after 1990 (Micurova, 2005).
} 
In Latvia, the Land Management Act (LML) ${ }^{27}$ states that the forthcoming land consolidation is voluntary, where all participants must accept the project. In overall, the lessors in land consolidation have no special status over other landowners, but as landowners, they are acting as the main contacts for authorities (Sproge, 2015). In Estonia, there was some land consolidation along with the land reform process, where the land ownership had a major role. However, there are aims to change the current legislation that possibly affects the land consolidation process (Jürgenson, 2015).

In Latvia, the recent change in the law on Land Privatisation in Rural Areas ${ }^{28}$ brought some changes to land use and ownership. The act currently states that land leases should be at least five years and must be informed to the municipal authorities. Additionally, there are restrictions on who is eligible to purchase agricultural lands (Sproge, 2015).

It is planned that the participants who will initiate the process fund these aforementioned land consolidations. However, this applies only to authorities, such as the state and municipalities. If landowners initiate the land consolidation, the cost of it is for the landowner, the state or the municipality (Sproge, 2015).

\section{EVALUATION}

To evaluate the results of this research, certain factors should be displayed. Where the focus was on qualitative material, the analysis was based on qualitative methods. Additionally, the statistical data from the European Union and its member states were used as background information for the analysis. The data was not further analysed.

To evaluate the process, there were several questions to be answered, for example, why the open survey was used as the primary method for acquiring the material. The survey was designed to be open rather than structured in order to give freedom to a participant to concentrate on the given topics that are essential in the current area. The given topics were to guide the participants to answer and keep separate surveys comparable. Moreover, due to the distances, the email survey was favoured over the interview.

Due to the requirements for a survey participant, only certain types of specialists, for example, representatives of authorities, were interviewed in the survey and not, for example, the lessors. The objective was to find out such specialists who had nationwide experience to present the situation in the whole country or area, thus outlining single lessors. To cover similar areas, by surveying the lessors, a substantially wider study has to be conducted. The surveyed areas were selected based on such criteria that the results would be generalisable in the most suitable way. In addition, the survey conducted in 2013 among Finnish lessors and specialists indicated that the specialists' understanding of the lessors' status was similar to the status that lessors themselves had experienced (Sulonen, 2014).

\footnotetext{
27 adopted on 1st January 2015.

${ }^{28}$ Since the 1 st November 2014.
} 


\section{DISCUSSION}

\section{WHAT IS THE SITUATION OF THE AGRICULTURAL LAND LEASE IN SURVEYED AREAS?}

The land lease on agricultural lands is common throughout Europe. There are factors that affect the commonness of land lease, such as current market prices, transaction capabilities, legislation and historical reasons. To be more specific, the land lease is affected by historical reasons, such as inheritance behaviour or the use of common farms and legislative differences like regulations on maximum and minimum rents per field hectare or lease periods.

The high lease prices seem to occur most likely in central Europe, especially in the North-West. In other surveyed areas of Europe, the prices for rent are lower in general.

\section{WHAT IS THE LESSOR'S STATUS IN LAND CONSOLIDATION IN COMPARISON WITH OTHER GROUPS?}

The lessor's status in land consolidation resembles the landowner's status in general (costs, hearing of participants, etc.). However, the lessor's status is unique in a way that lessors do not use their land by themselves and, therefore, benefits may be, or seem to be different to other landowners. There are special topics on land consolidation for the lessor, such as how the costs of the land consolidation are divided between the lessor and the leaseholder and what the status of the lease itself is.

Commonly, the leaseholders are not considered to have status as participants of land consolidation as lessors have. This is due to the temporary nature of the land lease. In addition, the length of the lease contract applies to how well the costs of the land consolidation can be distributed to leaseholders as land users. In areas, where the lease is common and has strong economic value, there are stronger protective rules for the leaseholder. In these areas, leaseholder's and lessor's statuses are similar.

In some cases, the allocation of the parcels might be done in respect of land use rather than land ownership, and the allocation is done if the landowner does not object it. Furthermore, in many cases the leaseholder's interests are passed on by their lessors.

The legislation for lease contracts of agricultural lands varies depending on how regulated the lease contract is between the parties. The regulations may apply only to certain types of land leases or lease contracts. For example, the land lease is more controlled in Finland in urban areas than in rural areas. Especially for field parcels without structures, the regulations allow short lease periods and oral contracts; whereas for urban plots, longer lease periods and written contracts are mandatory. On the other hand, there are strict regulations on agricultural land lease in Central European countries, such as France and the Netherlands, such as regulated rent and fixed renewable lease periods. These regulations support leaseholder's status and long-term lease contracts, thus allowing leaseholder to have some stability in land use. The stability might affect the leaseholder's interest to improve the land and to participate in land consolidation and in its costs more willingly. In countries such as the Netherlands, where the agricultural land 
lease can be registered, the rights of the leaseholders are close to the right of the lessors in such cases.

\section{HOW DO LESSORS SEEM TO EXPERIENCE THE LAND CONSOLIDATION?}

Lessors are commonly indifferent about the land consolidation and suspicious, especially before or at the beginning of the process. In the initiation stage, lessors may wish to be left out of the land consolidation process. As a whole, lessors tend to remain mostly indifferent, being neither strongly negative nor positive towards the land consolidation.

The lessor's reaction is based commonly on the concerns of the additional costs of land consolidation that they cannot distribute to the leaseholder. In areas where the rents of agricultural lands are high, the lessors may consider that they already have sufficient income of the investment and do not see additional investments necessary.

The lessors acknowledge land consolidation as a good way of improving the land use, but it is not a good investment for them. Where the leaseholder directly benefits of the land consolidation as the user of the land, lessor's benefits are more indirect and may seem less compelling for the lessor. Despite the lessors being commonly suspicious of land consolidation, they do not seem to be openly negative and their attitude tends to change slightly during the land consolidation.

\section{POSSIBLE DEVELOPMENT OF LESSOR'S STATUS}

The challenge in land consolidation is typically how to distribute the costs to participants in relation to the benefits. The leaseholder generally benefits from the land consolidation as the land user, but what if the leaseholder changes. On the other hand, the lessor's benefits of the land consolidation are more indirect and do not have the immediate effects.

If the weight of the land use increases and weight of the land ownership decreases on the parcel allocation, the statuses of the participants may be different in leaseholders' favour.

\section{FURTHER RESEARCH}

One of the interesting topics that occurred during the research was to investigate the landowner's reasons for the land lease. There seems to be a variation on this matter in surveyed areas. Some of the reasons are based on historical, economical or other factors affecting still the current markets, but finding out the landowner's reasons for land lease remains unclear. To examine this assumption, further research is needed. The different personal reasons for land lease can occur in land consolidations and may possibly affect the lessor's interests. 


\section{REFERENCES}

Auzina-Emsina, A., \& Ozolina, V. (2013). Export, Industrial Productivity and International Competitiveness: A Case of Latvia. Economics and Business, 24, 14-20. http://dx.doi.org/10.7250/eb.2013.002

Agrarbericht. Agricultural Report 2012. (2012). Bavarian State Ministry for Food, Agriculture and Forestry - orig. Bayerisches Staatsministerium für Ernährung, Landwirtschaft und Forsten (StMELF). Retrieved from http://www.agrarbericht-2012.bayern.de/tabellen-karten/schaubilder.html

CBS. Agricultural area in tenancy and ownership, 1970-2007. (2007). Statistics Netherlands orig. Centraal Bureau voor de Statistiek, source: CBS. Retrieved from http://www.cbs.nl/ nl-NL/menu/themas/landbouw/cijfers/incidenteel/maatwerk/2008-pachtgrond-maatwerk.htm

Ciaian, P., Kancs, d'Artis, Swinnen, J., Van Herck, K., Vranken, L. (2012). Rental Market Regulations for Agricultural Land in EU Member States and Candidate Countries. - Factor markets Coordination: Centre for European Policy Studies (CEPS). No. 15, February 2012. ISBN 978-94-6138-154-5. Retrieved from http://aei.pitt.edu/58518/1/Factor_Markets_15.pdf

Demetriou, D. Stillwell, J. See, L. (2013). A new methodology for measuring land fragmentation. Computers, Environment and Urban Systems, 39, 71-80. ISSN 0198-9715

DBV. Situation report 2014/15 trends and figures for agriculture - (orig. Situationsbericht 2014/15 trends und fakten zur landwirtschaft). (2014). German Farmer's Association (Deutscher Bauernverband). 24. November 2014. ISBN 978-3-9812770-6-7

Derlich, F. TS 7.4 Land Consolidation: A Key for Sustainable Development - French Experience. - FIG XXII International Congress. Washington, D.C. USA, April 2002. 19-26.

EU. (1987). Laying down detailed rules for the establishment of a Community vineyard register. European Union, Commission Regulation (EEC) No. 649/87, 3 March 1987. Retrieved from http://eur-lex.europa.eu/LexUriServ/LexUriServ.do?uri=CELEX:31987R0649:EN:HTML

EU. (2012). The Common Agricultural Policy - Luxembourg, Publications Office of the European Union. European Union. 2012. ISBN 978-92-79-23265-7. Retrieved from http://ec.europa.eu/ agriculture/50-years-of-cap/files/history/history_book_lr_en.pdf

Eurostat. Statistical office of the European communities. (2015). EUROSTAT: General and regional statistics. - Luxembourg. Publications Office of the European Union.

LCDoC. Natural Resources and Environment (2015). Republic of Cyprus, Ministry of Agriculture. Land Consolidation Department. Retrieved from http://www.moa.gov.cy/moa/lcd/lcd.nsf/ dmlmission_en/dmlmission_en?OpenDocument

Micurova, V. (2005). Latvia case study - Land consolidation. - Ministry of Agriculture, Latvia, Deputy Head of Rural Development Department.

Myyrä, S. (2009). Land leasing and agricultural productivity in Finland. Helsingin yliopisto, maatalous-metsätieteellinen tiedekunta, taloustieteen laitos. Doctoral dissertation. Tampereen yliopiston kirjapaino Juvenes print Oy. Tampere. ISBN 978-952-487-246-1 (print). ISBN 978952-487-246-1 (PDF).

NLS. (2013). Property sales statistics 2013 - Official Statistics of Finland. Helsinki 2013, ISBN 978-951-48-0241-6, ISSN 1799-6244. Retrieved from http://www.maanmittauslaitos.fi/ sites/default/files/kiinteistojen_kauppahintatilasto_2013.pdf

RDB. (2006). Rural Development in Bavaria. Voluntary land exchange. Publisher: Bavarian Ministry of Agriculture and Forestry. Rural Development. München.

Saarnilehto, A. (2006). Tenancy law. Principles and special regulation. WSOYpro. Helsinki. ISBN 951-0-31161-8.

Silvis, H. J. van der Meer en, R. W. Voskuilen, M. J. (2014). Pachtnormen 2014 - Berekening hoogst toelaatbare pachtprijzen voor los land, agrarische bedrijfsgebouwen en agrarische woningen. (eng. Lease Standards 2014 - Calculating maximum allowable rents for loose land, farm buildings and agricultural dwellings). Wageningen, LEI Wageningen UR (University \& Research centre).

Sulonen. K. (2014). Vuokranantajan asema tilusjärjestelysssä. Institute of Real Estate Studies. Aalto University. Master's thesis. Espoo. URN:NBN:fi:aalto-201404161688.

Sulonen, K. Kotilainen, S. (2016). Lessor's status on land consolidation in Finland. Nordic Journal of Surveying and Real Estate Research (NJSR). 11(1). 
Vitikainen, A. (2003). Development of the Land Consolidation Procedure. orig. Uusjakojen toimitusmenettelyn uudistamisesta. Publication of Real Estate and Economics studies. A 32. Helsinki University of technology. Doctoral dissertation. Espoo. ISBN 951-22-6530-3 (print), ISBN 951-22-6531-1 (PDF).

Vitikainen, A. (2004). An Overview of Land Consolidation in Europe. Nordic Journal of Surveying and Real Estate Research, (NJSR), 1/2004. 26-44.

Ylikangas, V. Peltotilusjärjestelyjen tarve ja mahdollisuudet Suomessa. Maanmittauslaitos. Publications of National Land survey of Finland number 95. ISBN 951-48-0180-6, ISSN 12365084.

\section{Legislation}

AoT Finnish legislation: Act on Tenancy (258/1966).

CRE Finnish legislation: Code of Real Estate (540/1995)

REFA Finnish legislation: Real Estate Formation Act (554/1995).

UjTL Finnish legislation: Act of subsidizing the land consolidations - orig. Laki uusjakojen tukemisesta (1423/2014)

The Finnish legislation can be accessed on the internet service Finlex. Retrieved from: http://www.finlex.fi/en/

RMFC French legislation: The rural and maritime fishing code-orig. Code rural et de la pêche maritime Articles L. 416-1; L. 411-5; L. 411-11). Retrieved from http://www.legifrance.gouv.fr/affichCode.do?cidTexte=LEGITEXT000006071367

LCA German legislation: Land Consolidation Act - orig. Flurbereinigungsgesetz (FlurbG)

\section{AUTHORS' SHORT BIOGRAPHY}

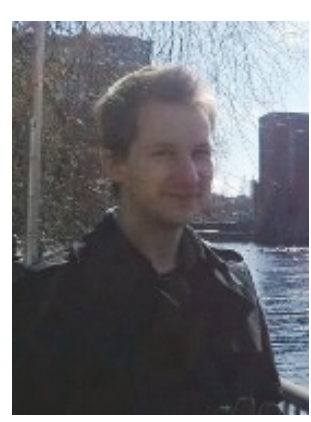

\section{Kimmo Sulonen}

Academic experience: He received the Master of Science in Technology (real estate planning) from Aalto University, 2014.

Practical experience: Municipal Cadastral Surveyor of City of Tampere since 2014, (Tampere, Finland). Land surveyor and GIS - responsible of city of Kauhava in the period of 2013-2014, GIS - specialist in Sito Company in the period of 2011-2013

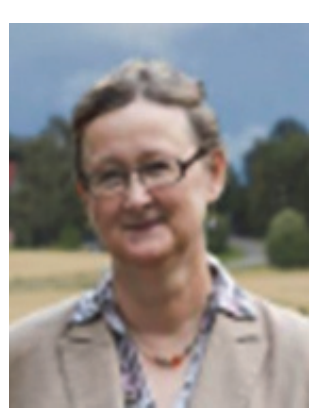

\section{Seija Kotilainen}

Academic experience: She received the Doctor of Science in Technology (land management) from Aalto University, 2013, Licentiate of Technology in Surveying from Helsinki University of Technology (HUT), 2003.

Practical experience: Senior Advisor at Centre for ICT Services of the National Land Survey of Finland since 2014, (Helsinki, Finland). Senior Advisor at the Development Centre of the National Land Survey of Finland in the period of 1990-2013. Cadastral Surveyor in several District Survey Offices in the period of 1981-1990.

Activities in homeland and international relations: Chair of the Finnish Society of Surveying Sciences (2004). Member of the Board of the Finnish Society of Surveying Sciences (1993-94, 2003, 2005). 